\title{
Mikrozonasi di Daerah Plampang, Nusa Tenggara Barat
}

\section{Microzonation in Plampang Area, West Nusa Tenggara}

\author{
Eko Rudi Iswanto*, Theo Alvin Riyanto, Hadi Suntoko \\ Pusat Kajian Sistem Energi Nuklir-BATAN \\ Jl. Kuningan Barat, Mampang Prapatan, Jakarta, Indonesia, 12710 \\ *E-mail: ekorudi@batan.go.id \\ Naskah diterima: 15 Februari 2021, direvisi: 21 April 2021, disetujui: 10 Mei 2021 \\ DOI: $10.17146 /$ eksplorium.2021.42.1.6243
}

\begin{abstract}
ABSTRAK
Provinsi Nusa Tenggara Barat (NTB) merupakan daerah dengan aktivitas kegempaan yang tinggi. Fenomena ini disebabkan oleh adanya aktivitas tektonik sebagai akibat pertemuan Lempeng Eurasia-Australia (zona subduksi) di bagian selatan dan Sesar Flores di bagian utara serta adanya keberadaan sesar-sesar lokal. Terkait dengan rencana pengembangan kawasan Samota di Pulau Sumbawa, NTB, perlu dilakukan suatu kajian kegempaan. Tujuan penelitian ini adalah memetakan indeks kerentanan seismik $\left(\mathrm{K}_{\mathrm{g}}\right)$ melalui pengukuran mikrotremor dengan analisis menggunakan metode Horizontal to Vertical Spectral Ratio (HVSR). Hasil penelitian berupa peta kerentanan seismik daerah Plampang yang menunjukkan bahwa sisi utara lokasi penelitian memiliki indeks kerentanan seismik rendah yang ditandai dengan nilai amplifikasi kurang dari tiga jika dibandingkan daerah lainnya. Geologi sisi utara lokasi penelitian tersusun oleh batuan gunung api dengan karakteristik batuan keras, ketebalan sedimen sangat tipis, dan tersusun atas batuan Tersier atau lebih tua. Peta kerentanan seismik berguna sebagai acuan dalam mitigasi gempa bumi untuk mengurangi risiko yang ditimbulkan.
\end{abstract}

Kata kunci: indeks kerentanan seismik, mikrotremor, HVSR

\begin{abstract}
Nusa Tenggara Barat (NTB) Province is an area with intense seismic activity. This phenomenon is caused by tectonic activity as the result of the convergency of the Eurasia-Australia Plates (subduction zone) in the south and the Flores Fault in the north as well as the presence of local faults. Regarding the plan to develop the Samota area in Sumbawa Island, NTB, a study concerning earthquakes should be done. The purpose of this study is to map the seismic vulnerability index $\left(K_{g}\right)$ through microtremor measurement by using the Horizontal to Vertical Spectral Ratio (HVSR) analysis method. The result of the study is a seismic vulnerability map of the Plampang area which its northern part has a low seismic vulnerability index indicated by the amplification factor value of less than three compared to other areas. The geology of the northern part of the Plampang area consists of volcanic rocks which has hard rock characteristic, very thin sediment thickness, and composed of Tertiary or older rocks. Seismic vulnerability maps can be useful as a reference for earthquake mitigation to reduce its risks.
\end{abstract}

Keywords: seismic vulnerability index, microtremor, HVSR 


\section{PENDAHULUAN}

Nusa Tenggara Barat (NTB) merupakan salah satu provinsi di Indonesia bagian timur yang memiliki aktivitas kegempaan yang tinggi. Hal ini disebabkan oleh adanya aktivitas tektonik sebagai akibat pertemuan Lempeng Eurasia-Australia (zona subduksi) di bagian selatan dan Sesar Flores di bagian utara serta adanya keberadaan sesar-sesar lokal. Sejarah kegempaan menunjukkan adanya beberapa kejadian gempa bumi merusak di wilayah ini. Sebagai contoh, pada 5 Agustus 2018 telah terjadi gempa bumi berkekuatan 7,0 Skala Richter (SR) di kedalaman $15 \mathrm{~km}$ dengan pusat gempa di timur Laut Lombok Utara. Tingkat kerusakan yang ditimbulkan dari suatu gempa bumi bergantung pada kekuatan gempa, kualitas bangunan yang ada, besarnya magnitudo, jarak pusat gempa, dan karakteristik bawah permukaan [1], [2]. Gempa Lombok tidak hanya menelan korban jiwa namun juga mengakibatkan kerugian ekonomi mengingat sektor pariwisata menjadi salah satu penopang utama ekonomi di provinsi ini.

Terkait rencana Pemerintah Provinsi NTB mengenai pengembangan kawasan Samota di Pulau Sumbawa dan mengingat potensi bahaya gempa yang telah dijelaskan sebelumnya maka suatu kajian kegempaan perlu dilakukan. Pada penelitian ini dilakukan kajian kegempaan berupa pengukuran mikrotremor di daerah Plampang, Pulau Sumbawa, NTB sebagaimana ditunjukkan pada Gambar 1. Pengukuran ini bertujuan memetakan indeks kerentanan seismik $\left(K_{g}\right)$ di daerah penelitian. Peta ini dibuat dengan mempertimbangkan karakteristik dinamika tanah yang berupa nilai frekuensi predominan ( $\left.\mathrm{f}_{0}\right)$ dan faktor amplifikasi $\left(\mathrm{A}_{0}\right)$ [3]-[5]. Tinggi rendahnya indeks kerentanan seismik berasosiasi dengan kondisi material bawah permukaan dan tingkat kerusakan akibat gempa bumi. Data hasil pengukuran dianalisis menggunakan metode Horizontal to Vertical Spectral Ratio (HVSR). Metode HVSR tidak menggunakan sumber gelombang buatan tapi memanfaatkan gelombang mikro yang ditimbulkan dari angin, gelombang aktivitas manusia, dan semacamnya [6]. Metode HVSR bersifat pasif sehingga efektif dan murah untuk karakterisasi kondisi bawah permukaan di area penelitian yang padat penduduk, seperti perkotaan [7]. Parameter bawah permukaan tersebut berupa nilai frekuensi predominan $\left(\mathrm{f}_{0}\right)$, faktor amplifikasi $\left(\mathrm{A}_{0}\right)$, dan indeks kerentanan sesimik $\left(\mathrm{K}_{\mathrm{g}}\right)$ [3], [4].

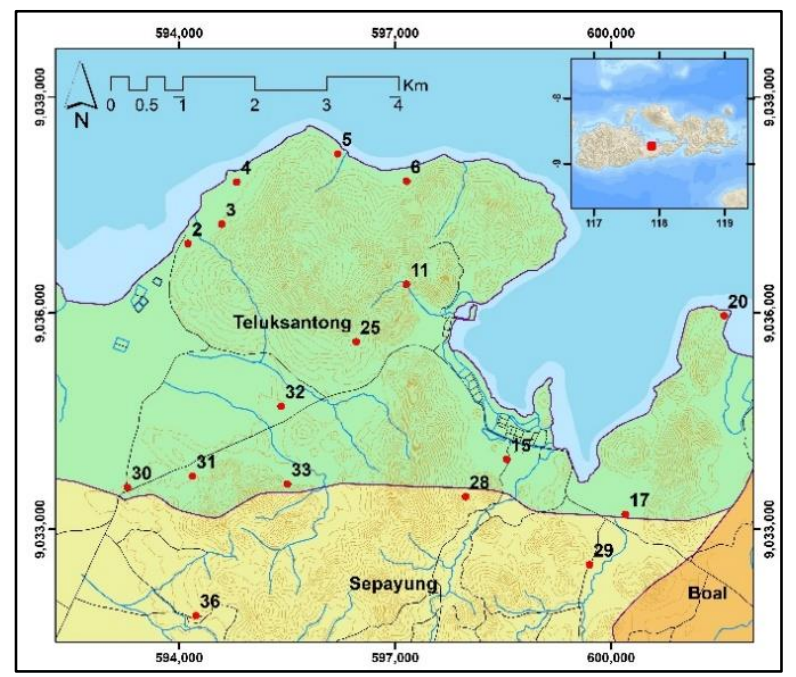

Gambar 1. Peta lokasi dan sebaran titik pengukuran mikrotremor di daerah Plampang, Pulau Sumbawa, NTB.

Pulau Sumbawa terdiri dari batuan vulkanik tua dan batuan vulkanik Kuarter yang ditutupi oleh endapan aluvium Kuarter (Gambar 2). Struktur geologi di Pulau Sumbawa sangat dipengaruhi oleh Sesar Naik Flores di sebelah utara, subduksi megathrust di sebelah selatan, dan sesar mendatar. Sesarsesar ini diduga sebagai sesar aktif dan memengaruhi kegempaan di Pulau Sumbawa. Struktur geologi di daerah penelitian berupa kekar dan sesar. Kekar berkembang pada batuan intrusif. Sesar dapat dideteksi melalui 
pola kelurusan topografi, DEM, dan zona breksiasi di lapangan. Sesar berkembang pada arah umum utara-selatan, barat laut-tenggara, dan barat daya-timur laut [8].

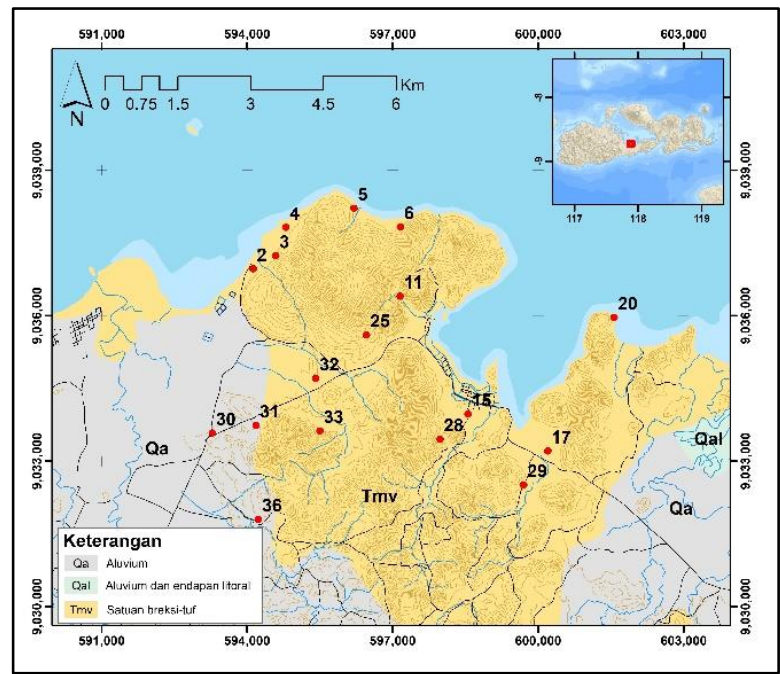

Gambar 2. Peta geologi lokal daerah Plampang, Pulau Sumbawa, NTB.

Secara geologis, batuan di daerah Plampang tersusun oleh Aluvium dan Endapan Pantai $\left(\mathrm{Q}_{\mathrm{al}}\right)$ serta Batuan Gunung Api $\left(\mathrm{T}_{\mathrm{mv}}\right)$ sebagaimana dapat dilihat pada Gambar 2 [8]. Aluvium dan Endapan Pantai $\left(\mathrm{Q}_{\mathrm{al}}\right)$ tersusun atas kerikil, pasir, lempung, lumpur dan pasir (terutama berupa andesit dan setempat mengandung magnetit). Batuan Gunungapi $\left(\mathrm{T}_{\mathrm{mv}}\right)$ yang tersusun atas breksi yang bersifat andesitik dengan sisipan tuf batuapung dan batupasir tufan, setempat mengandung lahar, lava andesit, dan basal. Batuan tersebut umumnya berwarna abu-abu dan hijau, setempat lava berstruktur bantal, bersisipan dengan rijang. Satuan batuan setempat terpropilitisasi, termineralisasi, dan tekersikkan; serta terdapat urat kuarsa dan kalsit. Umur batuan tersebut adalah Miosen.

\section{METODOLOGI}

Pengukuran mikrotremor dilakukan pada 28 titik yang tersebar dengan spasi sekitar $500 \mathrm{~m}$. Pengukuran di setiap titik dilakukan selama kurang lebih 15-30 menit dengan frekuensi sampling sebesar $100 \mathrm{~Hz}$. Data yang terekam disebut vibrasi tanah memiliki nilai amplitude displacement sekitar 0,1-1 mikron dan amplitude velocity 0,001-0,01 $\mathrm{cm} / \mathrm{dt}$ [9]. Data ini terdiri dari tiga komponen yaitu gelombang seismik horisontal (utaraselatan), horisontal (timur-barat), dan vertikal (up-down). Data tersebut juga memberikan gambaran respons spektral tanah dari suatu daerah studi [10]. Data dianalisis menggunakan metode HVSR dengan alur seperti pada Gambar 3

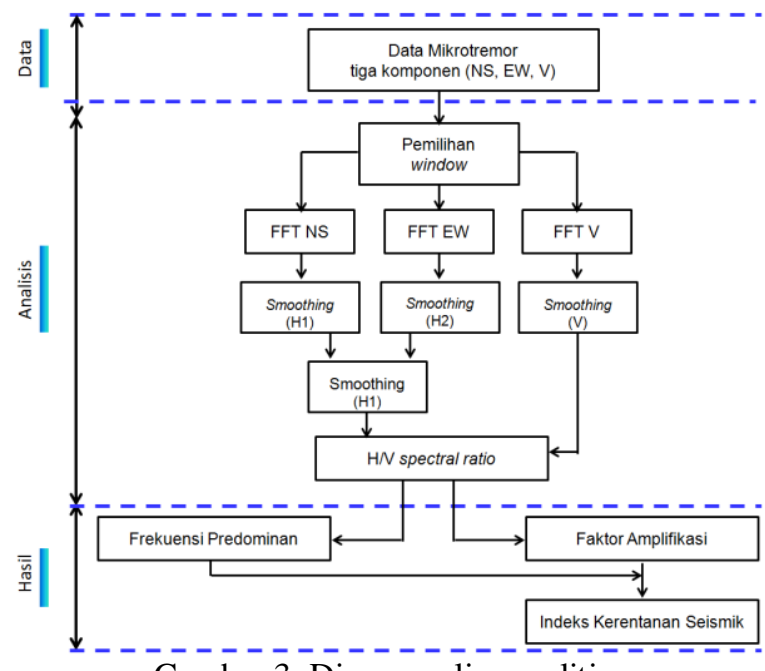

Gambar 3. Diagram alir penelitian.

Ketiga jenis sinyal gelombang di atas tercatat dalam domain waktu. Selanjutnya dilakukan proses picking dengan tujuan menghilangkan noise yang ikut terekam dalam data mikrotremor. Selanjutnya dilakukan analisis spektrum Fourier atau Fast Fourier Transform (FFT) untuk mengubah domain waktu menjadi domain frekuensi. Data yang dihasilkan dari proses FFT belum halus sehingga diperlukan filtering. Filtering dilakukan dengan cara smoothing untuk memperhalus data tersebut. Proses ini menggunakan filter smoothing Konno dan Ohmachi dengan koefisien bandwith 40 dan cosine taper 5\% [11]. Setelah FFT dan 
smoothing selesai, tiga komponen tersebut digabung ke dalam analisis HVSR menjadi spectral rasio amplitudo spektrum Fourier. Setelah didapat spektrum HVSR masingmasing window, rerata HVSR kemudian diplot. Hasil analisis berupa nilai frekuensi predominan $\left(\mathrm{f}_{0}\right)$ dan faktor amplifikasi $\left(\mathrm{A}_{0}\right)$.

\section{HASIL DAN PEMBAHASAN}

Hasil pengukuran berupa data rekaman mikrotremor sesuai dengan durasi masingmasing pengukuran. Contoh rekaman sinyal mikrotremor ditunjukkan pada Gambar 4 sedangkan contoh windowing dapat dilihat di Gambar 5 yang digunakan sebagai input untuk menghasilkan kurva HVSR.

Kurva HVSR terdiri dari garis hitam tegas yang menunjukkan kurva rata-rata HVSR dan garis hitam putus-putus yang menunjukkan simpangan kurva HVSR. Kurva HVSR pada Gambar 6 dan 7 menunjukkan kurva HVSR dengan satu puncak H/V yang jelas. Hal ini mengindikasikan adanya kontras impedansi pada suatu kedalaman tertentu sehingga gelombang teramplifikasi.

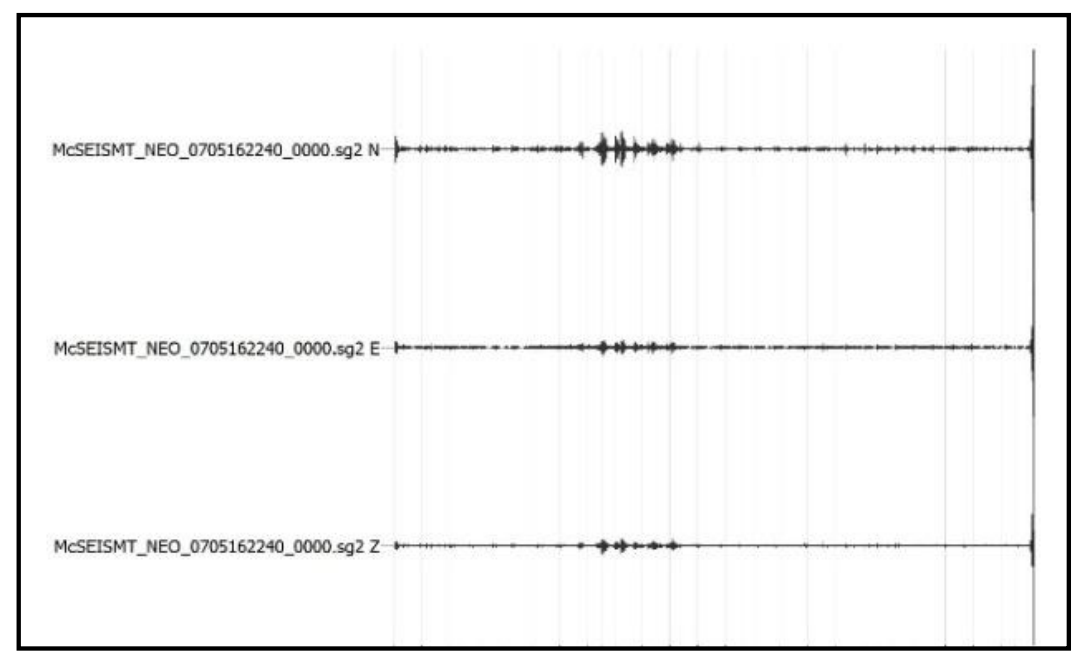

Gambar 4. Rekaman mikrotremor tiga komponen di titik ukur 15.

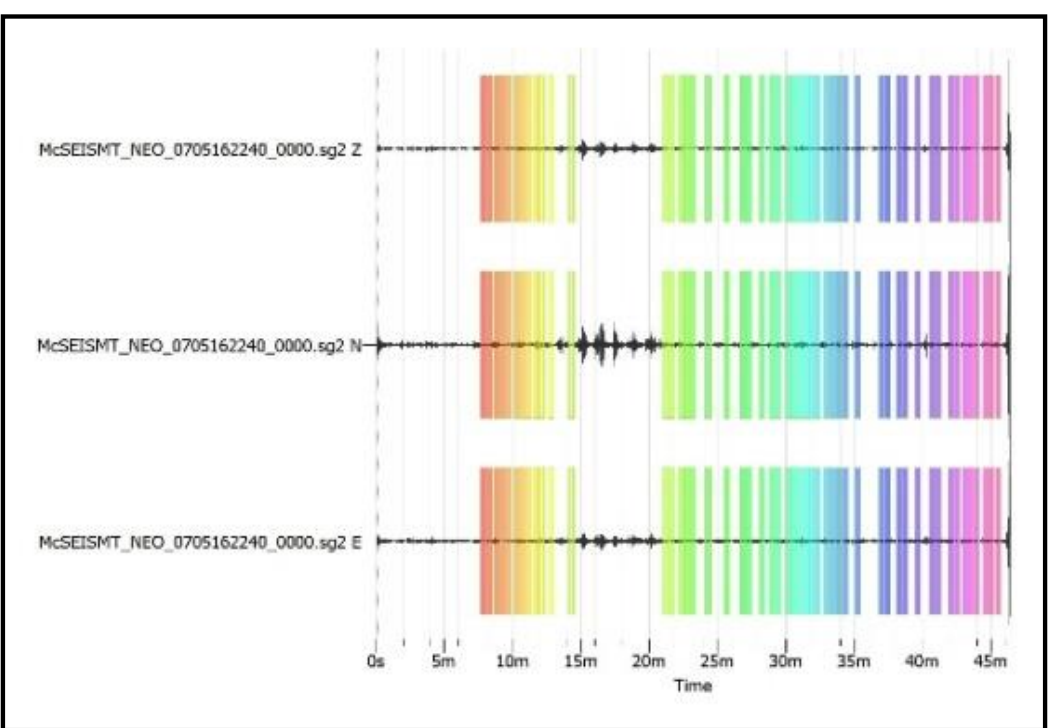

Gambar 5. Tahap windowing data mikrotremor di titik ukur 15 


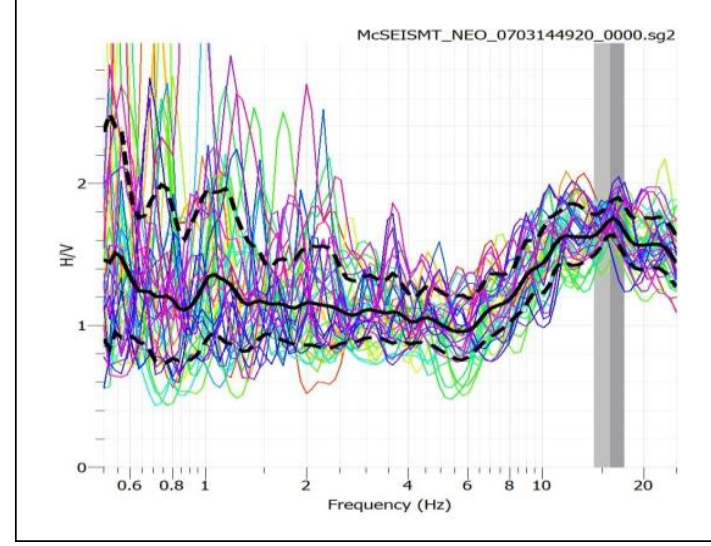

Gambar 6. Kurva HVSR titik ukur 5.

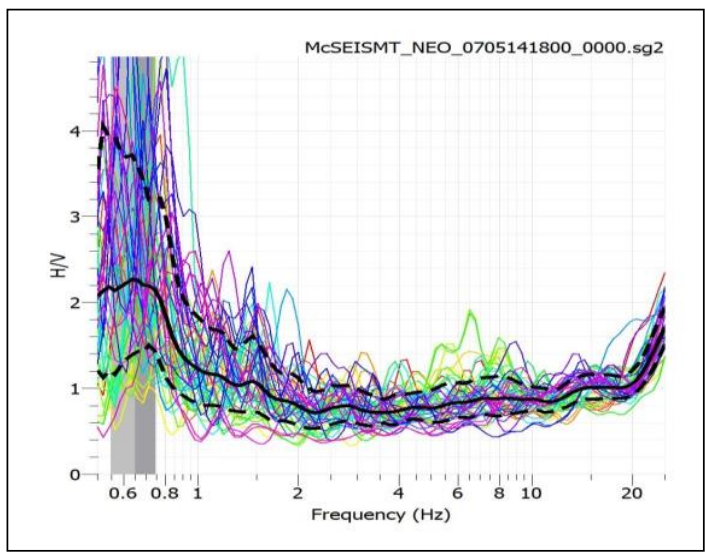

Gambar 7. Kurva HVSR titik ukur 29.

\section{Frekuensi Predominan}

Hasil analisis HVSR di sekitar Plampang menunjukkan nilai frekuensi predominan berkisar antara $0,6 \mathrm{~Hz}$ dan 22,2 $\mathrm{Hz}$. Plot sebaran nilai frekuensi predominan menunjukkan nilai frekuensi predominan tertinggi berada di titik ukur 28 sedangkan nilai frekuensi predominan terendah di titik ukur 29 sebagaimana dapat dilihat pada Gambar 8. Hal ini mengindikasikan bahwa lokasi di titik ukur 28 tersusun atas batuan keras. Ditinjau dari kolom stratigrafinya, lokasi di titik ukur 28 bertepatan dengan Batuan Gunungapi (Tmv) yang terdiri dari breksi yang bersifat andesitik dengan sisipan tuf batuapung dan batupasir tufan, setempat mengandung lahar, lava andesit, dan basal.
Lain halnya dengan titik ukur 29 yang memiliki nilai frekuensi predominan terendah, area tersebut berada di Aluvium dan Endapan Pantai (Qal) yang terdiri dari kerikil, pasir, lempung, lumpur, pasir (terutama andesit dan setempat mengandung magnetit). Hal ini menunjukkan bahwa titik ukur 29 memiliki lapisan sedimen yang lebih tebal dibandingkan titik ukur yang lain. Suatu daerah dengan karakteristik nilai frekuensi predominan rendah mengindikasikan bahwa daerah tersebut rentan terhadap bahaya getaran gelombang gempa bumi periode panjang yang dapat mengakibatkan kerusakan pada berbagai infrastruktur [12].

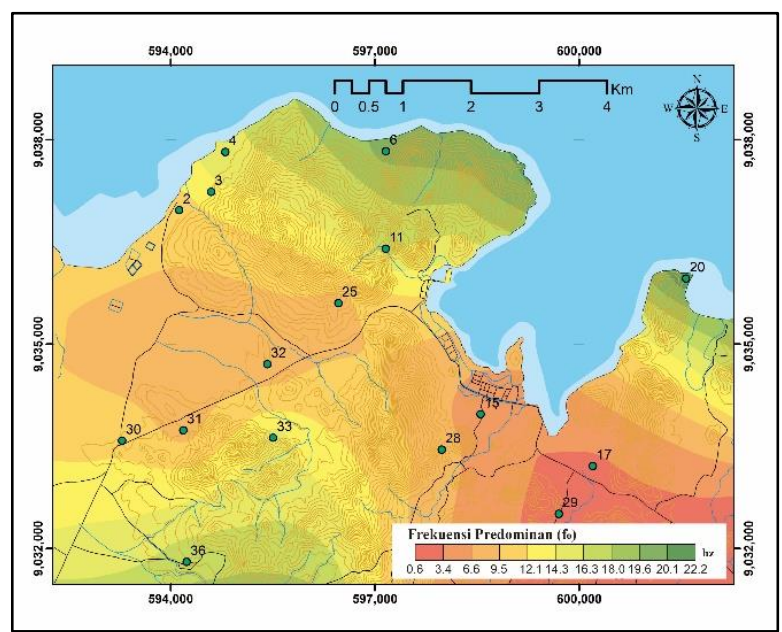

Gambar 8. Peta kontur frekuensi predominan $\left(\mathrm{f}_{0}\right)$

Peta sebaran frekuensi predominan tersebut menunjukkan bahwa daerah Plampang bagian utara (dekat dengan pantai) adalah daerah dengan frekuensi predominan yang lebih tinggi dibandingkan dengan lokasi lainnya. Nilai frekuensi predominan di lokasi tersebut sekitar 14,74-21,56 Hz. Tabel 1 menunjukkan klasifikasi tanah berdasarkan nilai frekuensi predominan mikrotremor. 
Tabel 1. Klasifikasi tanah berdasarkan nilai frekuensi predominan mikrotremor [13].

\begin{tabular}{|c|c|c|c|c|}
\hline \multicolumn{2}{|c|}{ Klasifikasi Tanah } & \multirow{2}{*}{$\begin{array}{c}\text { Frekuensi } \\
\text { Predominan } \\
(\mathrm{Hz}) \\
\end{array}$} & \multirow[b]{2}{*}{ Klasifikasi Kanai } & \multirow[b]{2}{*}{ Deskripsi } \\
\hline Tipe & Jenis & & & \\
\hline \multirow[t]{2}{*}{$\begin{array}{l}\text { Tipe } \\
\text { IV }\end{array}$} & Jenis I & $6,667-20$ & $\begin{array}{l}\text { Batuan Tersier atau lebih tua. } \\
\text { Terdiri dari hard sand, gravel, dll. }\end{array}$ & $\begin{array}{l}\text { Ketebalan sedimen } \\
\text { permukaan sangat tipis, } \\
\text { didominasi oleh batuan } \\
\text { keras. }\end{array}$ \\
\hline & Jenis II & $10-4$ & $\begin{array}{l}\text { Aluvium dengan ketebalan } 5 \mathrm{~m} \text {. } \\
\text { Terdiri dari sand-gravel, sandy } \\
\text { hard clay, loam, dll. }\end{array}$ & $\begin{array}{l}\text { Ketebalan sedimen } \\
\text { permukaan menengah }(5- \\
10 \mathrm{~m}) \text {. }\end{array}$ \\
\hline Tipe III & Jenis III & $2,5-4$ & $\begin{array}{l}\text { Aluvium dengan ketebalan > } 5 \mathrm{~m} \text {. } \\
\text { Terdiri dari sand-gravel, sandy } \\
\text { hard clay, loam, dll. }\end{array}$ & $\begin{array}{l}\text { Ketebalan sedimen } \\
\text { permukaan tebal (10-30 } \\
\text { m). }\end{array}$ \\
\hline Tipe II & Jenis IV & $<2,5$ & $\begin{array}{l}\text { Aluvium yang terbentuk dari } \\
\text { sedimentasi delta, top soil, } \\
\text { lumpur, dll. dengan kedalaman } 30 \\
\text { m atau lebih. }\end{array}$ & $\begin{array}{l}\text { Ketebalan sedimen } \\
\text { permukaan sangat tebal. }\end{array}$ \\
\hline
\end{tabular}

Berdasarkan klasifikasi tanah menurut nilai $\mathrm{f}_{0}$ mikrotremor sebagaimana dapat dilihat pada Tabel 1, bagian utara lokasi penelitian dapat diklasifikasikan sebagai tanah Tipe IV Jenis 1 dengan deskripsi tanah memiliki ketebalan sedimen yang sangat tipis dan tersusun atas batuan Tersier atau lebih tua. Lain halnya pada bagian tenggara yang memiliki frekuensi predominan rendah dengan nilai berkisar antara 0,65-2,73 Hz.

\section{Faktor Amplifikasi}

Spektrum HVSR tidak hanya menunjukkan $\mathrm{f}_{0}$ tapi juga menginformasikan nilai amplifikasi atau $\mathrm{A}_{0}$ suatu lokasi [14]. Amplifikasi merupakan penguatan gelombang seismik yang terjadi karena adanya perubahan medium yang signifikan [15]. Analisis HVSR di Plampang menunjukkan bahwa faktor amplifikasi bervariasi mulai dari 0,3 hingga 9,8 sebagaimana dapat dilihat pada Gambar 9. Faktor amplifikasi tertinggi berada di timur laut lokasi penelitian, yaitu di titik ukur 20 dengan nilai 14,78 sedangkan faktor amplifikasi terendah berada di tengah lokasi penelitian, yaitu di titik ukur 14 dengan nilai 1,47. Hal ini dapat mengindikasikan bahwa daerah di timur laut tersusun atas medium yang lebih lunak jika dibandingkan dengan daerah di tengah lokasi penelitian penelitian. Kondisi ini dapat mengakibatkan penguatan gelombang seismik ketika daerah di timur laut lokasi penelitian mengalami guncangan.

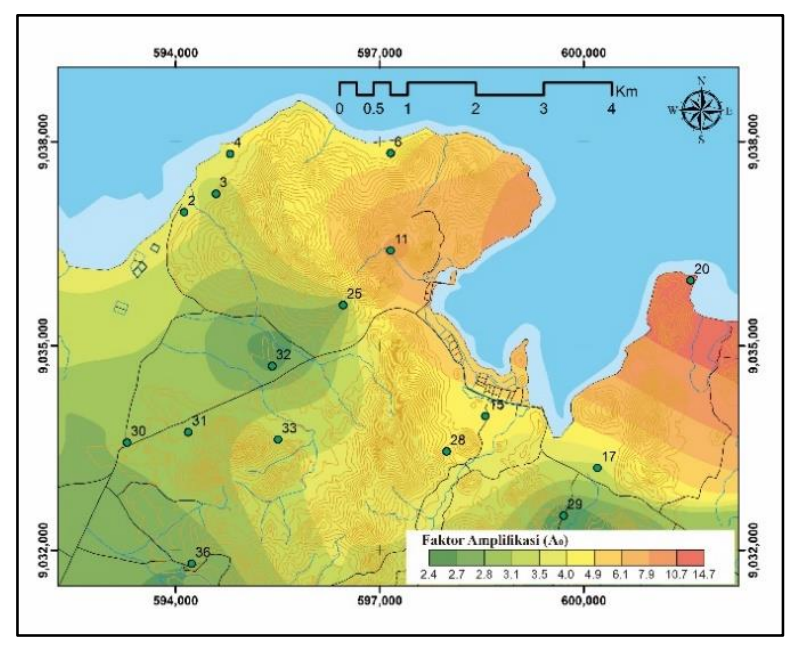

Gambar 9. Peta kontur amplifikasi $\left(\mathrm{A}_{0}\right)$.

\section{Indeks Kerentanan Seismik $\left(K_{\mathrm{g}}\right)$}

Indeks Kerentanan Seismik $\left(\mathrm{K}_{\mathrm{g}}\right)$ menggambarkan tingkat kerentanan lapisan tanah permukaan terhadap deformasi saat terjadi gempa bumi. Indeks kerentanan seismik berkaitan langsung dengan kondisi geomorfologis [16]. Indeks kerentanan seismik suatu daerah dan tingkat risiko gempa bumi menunjukkan adanya hubungan yang linier. 
Indeks kerentanan seismik diperoleh dari kuadrat faktor amplifikasi dibagi dengan nilai frekuensi predominan. Nilai indeks kerentanan seismik tinggi diperoleh dari area yang mempunyai nilai amplifikasi tinggi dengan nilai frekuensi dominan rendah. Semakin tebal lapisan sedimen di suatu daerah semakin besar pula amplifikasi yang terjadi saat gempa bumi [17]. Peta kontur indeks kerentanan seismik dapat dilihat pada Gambar 10.

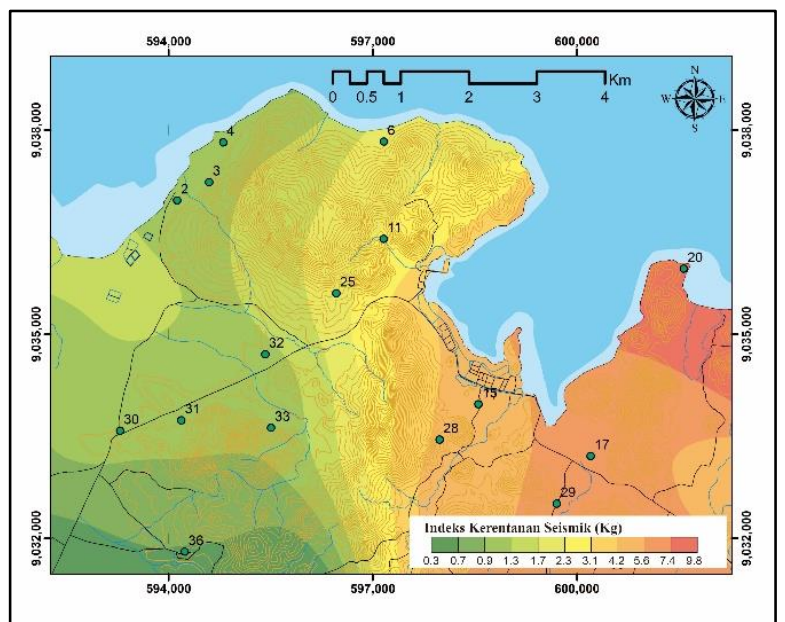

Gambar 10. Peta kontur indeks kerentanan seismik $\left(\mathrm{K}_{\mathrm{g}}\right)$.

Sebaran nilai indeks kerentanan seismik di daerah Plampang beragam dengan rentang 0,25-12,35 sebagaimana ditunjukkan pada Gambar 10. Nilai tertinggi berada di titik ukur 29 yang terletak di tenggara lokasi penelitian, bertepatan dengan Aluvium dan Endapan Pantai dengan karakteristik sedimen lunak. Berbeda halnya dengan titik ukur 33 yang berada di utara yang memiliki nilai indeks kerentanaan terendah, daerah ini bertepatan dengan Batuan Gunung Api dengan karakteristik batuan keras. Berdasarkan nilai indeks kerentanan seismik dan kondisi geologi tersebut diperoleh bahwa daerah di bagian utara-barat laut memiliki tingkat risiko gempa bumi yang lebih rendah daripada daerah di bagian selatan-tenggara.

\section{KESIMPULAN}

Peta kerentanan seismik yang dihasilkan dalam penelitian ini menunjukkan bahwa bagian utara daerah Plampang memiliki indeks kerentanan seismik rendah yang ditandai dengan nilai amplifikasinya yang kurang dari tiga. Geologi sisi utara lokasi penelitian tersusun atas Batuan Gunungapi dengan karakteristik batuan keras, ketebalan sedimen sangat tipis, serta berumur Tersier atau lebih tua. Peta kerentanan seismik dapat berguna sebagai acuan mitigasi untuk mengurangi risiko yang ditimbulkan gempa bumi.

\section{UCAPAN TERIMA KASIH}

Penelitian ini didukung dan didanai oleh Pusat Kajian Sistem Energi Nuklir, Badan Tenaga Nuklir Nasional (PKSEN - BATAN) Tahun Anggaran 2019. Para penulis menyatakan bahwa semua menjadi kontributor utama dalam kegiatan penelitian ini yang meliputi kegiatan pengukuran, pengolahan dan analisis data lapangan, hingga penulisan makalah.

\section{DAFTAR PUSTAKA}

[1] Sungkono dan B. J. Santosa, "Karakterisasi Kurva Horizontal-To-Vertical Spectral Ratio: Kajian Literatur Dan Permodelan," J. Neutrino, vol. 4, no. 1, hal. 1-15, 2011, doi: 10.18860/neu.v0i0.1662.

[2] Sunaryo, H. U. Mala, dan A. Prasetio, "Earthquake Microzonation Study on Batu Besi Dam of Nuha, East Luwu, South Sulawesi, Indonesia," Int. J. GEOMATE, vol. 15, no. 48, hal. 148-154, 2018.

[3] M. Herak, "Model HVSR - A Matlab tool to model horizontal-to-vertical spectral ratio of ambient noise," Comput. Geosci., vol. 34, no. 11, hal. 1514-1526, 2008, doi: 10.1016/j.cageo.2007. 07.009 .

[4] J. Saita, M. Bautista, dan Y. Nakamura, "On Relationship Between The Estimated Strong 
Motion Characteristics Of Surface Layer And The Earthquake Damage," in 13 th World Conference on Earthquake Engineering, 2004, no. 905, hal. 1-7.

[5] R. Carniel, P. Malisan, F. Barazza, dan S. Grimaz, "Improvement of HVSR technique by wavelet analysis," Soil Dyn. Earthq. Eng., vol. 28, no. 4, hal. 321-327, 2008, doi: 10.1016/j.soildyn.2007. 06.006.

[6] J. W. Lane Jr., E. A. White, G. V. Steele, dan J. C. Cannia, "Estimation of Bedrock Depth Using the Horizontal- to- Vertical (H/V) Ambient- Noise Seismic Method," in Environmental and Engineering Geophysical Society, 2009, hal. 490-502, doi: 10.4133/1.2963289.

[7] P. Guéguen, J. L. Chatelain, B. Guillier, dan H. Yepes, "An indication of the soil topmost layer response in Quito (Ecuador) using noise H/V spectral ratio," Soil Dyn. Earthq. Eng., vol. 19, no. 2, hal. 127-133, 2000, doi: 10.1016/S02677261(99)00035-4.

[8] A. Sudradjat, S. A. Mangga, dan N. Suwarna, "Peta Geologi Lembar Sumbawa, Nusatenggara," Bandung, 1998.

[9] M. Mirzaoglu dan U. Dykmen, "Application of microtremors to seismic microzoning procedure," J. Balk. Geophys. Soc., vol. 6, no. 3, hal. 143156, 2003.

[10] M. Sutrisna, C. Sulaeman, dan N. D. Ardi, "Microtremor Methode for Microzonation in Cilacap City," J. Online Fis., vol. 3, no. 2, hal. 113, 2015.

[11] K. Konno dan T. Ohmachi, "Ground-Motion Characteristics Estimated from Spectral Ratio between Horizontal and Vertical Components of Microtremor," Bull. Seismol. Soc. Am., vol. 88, no. 1, hal. 228-241, 1998.
[12] Daryono, Sutikno, J. Sartohadi, Dulbahri, dan K. S. Brotopuspito, "Pengkajian Local Site Effect di Graben Bantul Menggunakan Indeks Kerentanan Seismik Berdasarkan Pengukuran Mikrotremor," J. Kebencanaan Indones., vol. 2, no. 1, hal. 456467, 2009.

[13] S. S. Arifin, "Penentuan Zona Rawan Guncangan Bencana Gempa Bumi Berdasarkan Analisis Amplifikasi HVSR Mikrotremor dan Analisis Periode Dominan Daerah Liwa dan Sekitarnya," J. Geofis. Eksplor., vol. 2, no. 1, hal. 30-40, 2018.

[14] Saadudin, Sismanto, dan Marjiyono, "Pemetaan Indeks Kerentanan Seismik Kota Padang Sumatera Barat Dan Korelasinya Dengan Titik Kerusakan Gempabumi 30 September 2009," in Seminar Nasional Kebumian Ke-8, 2015, hal. 459-466.

[15] N. Sitorus, S. Purwanto, dan W. Utama, "Analisis Nilai Frekuensi Natural dan Amplifikasi Desa Olak Alen Blitar Mengguakan Metode Mikrotremor HVSR," J. Geosaintek, vol. 03, no. 02, hal. 89-92, 2017.

[16] A. I. Hadi, M. Farid, dan Y. Fauzi, "Pemetaan Percepatan Getaran Tanah Maksimum dan Kerentanan Seismik Akibat Gempa Bumi untuk Mendukung Rencana Tata Ruang dan Wilayah (RTRW) Kota Bengkulu," SIMETRI, J. Ilmu Fis. Indones., vol. 1, no. 2D, hal. 81-86, 2012.

[17] R. A. Murdiantoro, Sismanto, dan Marjiyanto, "Pemetaan Daerah Rawan Kerusakan Akibat Gempabumi di Kotamadya Denpasar dan Sekitarnya dengan Menggunakan Analisis Mikrotremor Studi Kasus : Gempabumi Seririt 14 Juli 1976," J. Fis. Indones., vol. 20, no. 2, hal. 36-41, 2016. 